\title{
Kapital powraca
}

\author{
Istota depresji gospodarczych z lat siedemdziesiatych byto to, \\ że zmusity burżuazję do uświadomienia sobie po raz pierwszy, \\ że pierworodny grzech zwyktego rabunku, który przed wiekami \\ umożliwit "pierwotna akumulacje kapitatu” (Marks) \\ i uruchomit wszelka dalsza akumulację nagle nie zgast.
}

Brzmi znajomo? Pewnie to słowa jakiejś współczesnej marksistki, radykalnie negującej zasadność dalszego istnienia kapitalizmu, prawda? Otóż nie jest to cytat z Davida Harveya. Nie dotyczy też zmiany światowego ładu gospodarczego po kryzysie naftowym. To uwaga Hanny Arendt dotycząca sięgających schyłku dziewiętnastego stulecia imperialistycznych korzeni totalitaryzmu ${ }^{1}$.

W innym miejscu autorka ta konstatowała:

Gospodarka kapitalistyczna, funkcjonując w systemie społecznym opartym na wadliwym podziale, niesłychanie pomnożyła bogactwo doprowadzając do „nadmiernego oszczędzania”, to jest do akumulacji kapitału skazanego na nieproduktywność w ramach krajowych możliwości produkcyjnych i konsumpcyjnych².

Efektem były pozbawione politycznej kontroli inwestycje zagraniczne, „wywołujące niesłychaną orgię oszustw, skandali finansowych i spekulacji giełdowych" ${ }^{3}$. Uwagi te odnoszą się do bardzo specyficznego momentu historycznego - belle époque, kiedy to zamożna Europa korzystała z niespotykanie długiego okresu pokoju i stabilności. Był to jednakże spokój pozorny. Sama epoka brzemienna już była nadchodzącą, na pierwszy rzut oka pozbawioną sensu, wojną mocarstw. Nie przypadkiem w swoich dociekaniach nad tym niespokojnym okresem za swoją przewodniczkę Arendt obrała Różę Luksemburg. Dostrzegała w niej nie tylko teoretyczkę i praktyczkę specyficznej formy doświadczenia politycznego ${ }^{4}$, ale przede wszystkim przenikliwą ekonomistkę, która jako

1 H.Arendt, Korzenie totalitaryzmu, tłum. D. Grinberg, M. Szawiel, Warszawa 2008, s. 220.

2 Tamże, s. 219.

3 Tamże, s. 220.

4 Zadłużenie Arendt u Luksemburg w tym zakresie jest częściej rozpoznawane, zob. H.Arendt, Rosa Luxemburg, [w:] Men in Dark Times, New York 1970; T. Storlokken, Frauen in Finsteren Zeiten - Rosa Luxemburg und Hannah Arendt, 
pierwsza z taką wyrazistością pokazała konsekwencje nadakumulacji i finansjeryzacji kapitalizmus.

Najważniejsze dzieło ekonomiczne Róży Luksemburg, Akumulacja kapitatu: przyczynek do ekonomicznego wyjaśnienia imperializmu - pisane w chwili, gdy stary ład coraz mocniej chwiał się w posadach - zostało wydane niemalże w przeddzień I wojny światowej, w 1913 roku$^{6}$. Nie przypadkiem fala wznowień i nowego zainteresowania książką Luksemburg przypada na pierwszą dekadę dwudziestego pierwszego wieku ${ }^{7}-$ w niemal sto lat od jej pierwszego wydania.

Porównując kształt kapitalistycznego świata u początku dwudziestego stulecia z dzisiejszą sytuacją, spostrzeżemy zaskakujące podobieństwa: bezpośrednie inwestycje zagraniczne (BIZ) osiągnęły w 1913 roku 9\% wartości światowej produkcji - a więc wielkość, do której zbliżono się ponownie dopiero w latach dziewięćdziesiątych dwudziestego wieku' Również udział handlu zagranicznego w PKB największych krajów kapitalistycznych w 1993 roku był bardzo zbliżony do tego z 1913 roku' Okazuje się więc, że globalizacja, jaką znamy z debat z lat dziewięćdziesiątych, nie była czymś bez precedensu w historii; specyficzne dla niej było przede wszystkim znaczące zwiększenie udziału i roli rynków finansowych w gospodarce ${ }^{10}$. Są jednak poważne przesłanki by - jak czyni to choćby Giovanni Arrighi - dopatrywać się pewnych analogii pomiędzy sfinansjeryzowanym kapitalizmem dnia dzisiejszego a kryzysem nadakumulacji opisywanym tak skrupulatnie przez Luksemburg w $1913 \mathrm{roku}^{11}$.

[w:] China endeckte Rosa Luxemburg, Berlin 2007; F. Moreault, Hannah Arendt, lectrice de Rosa Luxemburg, "Canadian Journal of Political Science/Revue canadienne de science politique" 2001, Vol. 34, No. 02.

5 Zob. H.Arendt, Rosa Luxemburg...

6 Na marginesie warto dodać, że możliwość rychłego wybuchu wojny Luksemburg prognozowała w ostatnim rozdziale swojej książki, poświęconym militaryzmowi jako sposobowi na rozwiązanie problemu nadprodukcji.

7 Zob. R. Luksemburg, The Accumulation of Capital, London, New York 2003; nowe wydanie polskie: Akumulacja kapitatu: przyczynek do ekonomicznego wyjaśnienia imperializmu, tłum. J. Maliniak, Z. Kluza-Wołosiewicz, J. Nowacki, przedm. T. Kowalik, Warszawa 2011.

8 P. Bairoch, R. Kozul-Wright, Globalization Myths: Some Historical Reflections on Integration, Industrialization and Growth in the World Economy, UNCTAD Discussion Paper 1996, No. 13, s. 10.

9 P. Hirst, Global Market and the Possibilities of Governance, Paper presented at the Conference on Globalization and the New Inequality, University of Utrecht, November 20-22, 1996, s. 3-4.

10 S.Sassen, Losing Control?: Sovereignty in an Age of Globalization, New York 1996, s. 40.

11 G. Arrighi, The Long Twentieth Century, London-New York 1994; tegoż 
W obydwu przypadkach możemy bez trudu zaobserwować podobne skutki tych procesów: wzmożenie łupieżczych praktyk kapitału (czy to w postaci utrzymującej się ciągle akumulacji pierwotnej ${ }^{12}$, czy też kolejnych cykli akumulacji przez wywłaszczenie $\left.{ }^{13}\right)$, niestabilność nastawionej na spekulację gospodarki ${ }^{14}$ czy instrumentalizowanie przez kapitalizm różnych odmian nacjonalizmu ${ }^{15}$.

Nie musimy jednak zapatrywać się na te zjawiska w sposób podobny do proponowanego przez Arrighiego czy Fernanda Braudela, którzy z pewnym fatalizmem stwierdzają cykliczność przemian, jakim ulega świat kapitalistyczny. Być może nie jesteśmy skazani na formułę: wzrost potęgi dominującego państwa kapitalistycznego - uzyskanie przez nie przewagi na światowym rynku - nadakumulacja, ekspansja i spekulacja - destabilizacja - zmiana światowej hegemonii. Róża Luksemburg opisując pułapkę akumulacji kapitału, dostrzegała w rozwoju kapitalizmu raczej pewien proces, który wytwarza warunki swojego przyszłego zniesienia jako formy organizacji produkcji. Fatalistycznej, cyklicznej wizji przeciwstawiała specyficzny rodzaj optymistycznego, ale dalekiego od naiwności progresywizmu.

Zdaniem Róży Luksemburg, potrzeba realizacji wartości dodatkowej zmusza kapitalizm do poszukiwania zbytu na rynkach niekapitalistycznych. Z drugiej jednak strony, konieczność kapitalizacji powoduje nieustanne wciąganie w obręb systemu jego niekapitalistycznego otoczenia - dokonuje się zatem proces internalizacji zewnętrza ${ }^{16}$. Dzieje się tym samym rzecz paradoksalna: kapitał podcina gałąź, na której sam siedzi. Bariery mogą być bowiem przekraczane tylko dopóty, dopóki możliwa jest postępująca ekspansja. „Zależność kapitału od zewnętrza, od jego niekapitalistycznego otoczenia, zaspokajająca potrzebę realizacji wartości dodatkowej” - słowami Michaela Hardta i Antonio Negriego - „pozostaje

Globalization, State Sovereignty and the „Endless” Accumulation of Capital, [w:] The Ends of Globalization: Bringing Society Back In, red. D. Kalb [i in.], London 2000.

12 T.D.Wilson, Primitive Accumulation and the Labor Subsidies to Capitalism, "Review of Radical Political Economics" 2011, No. X.

13 D. Harvey, The New Imperialism, New York 2003.

14 J. Toporowski, Theories of Financial Disturbance: an Examination of Critical Theories of Finance from Adam Smith to the Present Day, Cheltenham 2005.

15 Zob. H.Arendt, Korzenie totalitaryzmu; D. Harvey, Neoliberalizm: historia katastrofy, Warszawa 2008; J. Friedman, Globalization, Dis-integration, Re-organization: the Transformation of Violence, [w:] Globalization, the State, and Violence, red. J.Friedman, Walnut Creek 2003.

16 M. Hardt, A. Negri, Imperium, tłum. M. Kołbaniuk, S. Ślósarski, Warszawa 2005, s. 245. 
w sprzeczności z internalizacją niekapitalistycznego otoczenia, zaspokajającą potrzebę kapitalizacji owej zrealizowanej wartości dodatkowej"17.

Należy jednak nieco ostudzić powyższy optymizm. Analiza historycznej trajektorii kapitalizmu pokazuje bowiem, że zdolność poszerzania tego niezbędnego zewnętrza, nie tylko poprzez ekspansję terytorialną, ale przede wszystkim utowarowienie kolejnych sfer życia i powtarzalne zawłaszczanie różnego rodzaju dóbr wspólnych (tak naturalnych, jak i trudniej poddających się grodzeniom elementów kulturowych) jest zaskakująco duża i dalece przekracza granice, o których myślała Luksemburg.

Nietrudno wskazać też na pewne tendencje rozwojowe kapitalizmu, które autorka Akumulacji kapitatu uważała za nieuchronnie prowadzące do jego implozji, a które okazały się możliwe do odwrócenia. Najbardziej spektakularnym przykładem może być przekonanie o konieczności sukcesywnego zmniejszania się płacy względnej. Tendencja ta, podsycająca nadzieję Luksemburg na rychłą rewolucję, w pewnym momencie nie tylko się zatrzymała, ale nawet na krótki czas odwróciła się. Po II wojnie światowej nie tylko płace realne, ale również udział płac w dochodzie narodowym w wielu państwach kapitalistycznych rósł.

Ponowne spojrzenie na wiek dwudziesty zachęca do jeszcze innego ujęcia sprawy, które w ciekawym świetle stawia dorobek Luksemburg. Analiza dynamiki kapitalizmu od strony samego kapitału, uprawiana przez kolejne pokolenia marksistowskich teoretyków, nie uwzględnia w zasadzie walki klas jako siły wpływającej na targaną wstrząsami ewolucję kapitalizmu. Zadanie niedokończone przez Marksa (w nigdy nienapisanych, a jedynie planowanych tomach Kapitatu) nie znalazło też pełnego rozwinięcia u Luksemburg. Trwająca kilkadziesiąt lat geograficzna i historyczna aberracja, jaką było (a gdzieniegdzie wciąż jest) zachodnie państwo dobrobytu, nie powstała w wyniku działania jakichś tajemnych sił albo „praw historycznych”. Państwo dobrobytu powstało i zniknęło (a może wciąż zanika) na skutek walki klasowej sensu largo. Długotrwałe i ciężkie walki społeczne ruchu robotniczego, a także realne istnienie alternatywy (choć z biegiem lat coraz mniej kuszącej) w postaci „komunistycznego” ZSRR i bloku wschodniego spowodowały przechylenie szali zwycięstwa na stronę klasy robotniczej. Świetnie zorganizowana walka klasowa, w połączeniu ze „straszakiem” z Moskwy, zmusiły kapitał do niespotykanych wcześniej w historii ustępstw. Te sukcesy nieco już jednak wyblakły. Walka klasowa prowadzona przez kapitał - wykorzystująca wszystkie dostępne narzędzia, takie jak np. postęp technolo-

17 Tamże, s. 247. 
giczny, geograficzne zróżnicowanie płac $^{18}$ i przestrzenny podział pracy ${ }^{19}$, wytwarzanie nadwyżkowych populacji i rezerwowych armii pracy, eksternalizacja kosztów reprodukcji siły roboczej, wzmaganie horyzontalnej polaryzacji społecznej ${ }^{20}$ i przekierowywanie klasowego gniewu na czynniki kulturowe $e^{21}$ - zawróciła nas z powrotem na tory, którymi zmierzał kapitalizm w czasach Luksemburg 22 .

Doskonale wiemy, że poszukiwanie łatwych historycznych analogii to zajęcie dobre dla gabinetowych konserwatystów. W ciągu stu lat, które minęły od wydania Akumulacji kapitatu, świat znacznie się zmienił, a kapitalizm nie jest już taki jak kiedyś. Dlatego też bezmyślne podążanie za wskazówkami tej, bądź co bądź, wybitnej myślicielki, byłoby co najwyżej parodią radykalnej polityki i dość daleko odbiegałoby od ducha przenikającego pisma Luksemburg. Jednocześnie jednak uważamy, że zmagała się ona z podobnym rodzajem teoretycznego wyzwania i politycznego doświadczenia, które stały się obecnie również naszym udziałem. W pierwszym z tych aspektów dziedzictwo Róży Luksemburg jest przede wszystkim nieustającym punktem odniesienia dla badaczy kapitalistycznej akumulacji, ekspansji i wywłaszczenia. Może też stać się cennym impulsem w zakresie badania bariery popytu w rozwoju kapitalizmu, roli finansów w kapitalistycznej gospodarce, a także inspiracją dla teorii podkreślających rolę obiegu pieniężnego. W prezentowanym numerze zagadnienia te przybliżają teksty Massimo de Angelisa, Michaela Löwy’ego, Riccardo Bellofiorego, Marco Passarelli oraz Macieja Szlindera. Echa twierdzeń przedstawionych przed laty przez Luksemburg pobrzmiewają dziś również w dynamicznie rozwijanej krytycznej teorii neoliberalizmu.

18 Zob. M. Tomba, Zróżnicowanie wartości dodatkowej we wspótczesnych formach wyzysku, tłum. W. Marzec [w:] Wieczna radośc: ekonomia polityczna spotecznej kreatywności, red. zespół, Warszawa 2011.

19 D. Massey, Spatial Divisions of Labor: Social Structures and the Geography of Production, London-New York 1995.

20 J. Friedman, Globalization...

21 Zob. np. klasyczna analizę E. Blocha, Nonsynchronism and the Obligation to Its Dialectics, "New German Critique" 1977, No. 11; T. Frank, Co z tym Kansas: czyli opowieść o tym, jak konserwatyści zdobyli serce Ameryki, tłum. J. Kutyła, Warszawa 2008, D. Ost, Klęska „Solidarności”: gniew i polityka w postkomunistycznej Europie, tłum. H. Jankowska, Warszawa 2007.

22 Oczywiście neoliberalnej transformacji nie można zredukować do knowań ekonomistów z Mont Pelerin Society, zmowy kapitalistów czy nawet samoprzekształceń państw rozumianych jako „komitety wykonawcze burżuazji”, niemniej jednak obecny jest w niej aspekt odgórnej walki klasowej. Na temat istoty neoliberalizmu i jego historycznych trajektorii zob. np. debatę w bieżącym i poprzednim numerze „Praktyki Teoretycznej”. 
Ostatecznie teza o konieczności internalizacji niekapitalistycznego zewnętrza zdradza (niekoniecznie wprost) postawę obcą większości współczesnych ekonomistów - wrażliwość na kontekst kulturowy, uwarunkowania geograficzne oraz społeczno-polityczne trajektorie. Kapitalizm roku 1913 i ten o blisko wiek późniejszy są w tej samej mierze uzależnione od swoich „znaczących innych”. W prezentowanym numerze przypominają nam o tym Jamie Peck i Nik Theodore, autorzy jednej z ciekawszych odpowiedzi na opublikowany przez nas w poprzednim numerze artykuł Loïca Wacquanta.

Drugie wspomniane pole naszego szczególnego zainteresowania to filozofia polityczna i teoria procesu rewolucyjnego. Chodzi nam tu przede wszystkim o próbę wyczytania z pism Róży Luksemburg świadectw zmagań z polityczną materią - zmagań, w których i my dzisiaj bierzemy udział. W jej dociekaniach nad polityczną mobilizacją, strajkiem masowym i mozolnym budowaniem podmiotu rewolucyjnej zmiany tkwi coś więcej niż tylko zapis teoretycznej samoświadomości autorki. Oczywiście nie można dziś bezpośrednio przywrócić tradycji ówczesnego myślenia; chodziłoby raczej o zrozumienie, że pozwala nam ona odkryć podstawowe doświadczenia, z których wyrasta. Pełen pasji i emocji, a momentami wstrząsający zapis zmagań rewolucyjnych prowadzonych przez przekonaną o konieczności radykalnej zmiany teoretyczkę i działaczkę daje poruszający wgląd w taką zmianę i możliwość jej współmyślenia. Stąd nasza decyzja o publikacji czterech tekstów Luksemburg niedostępnych dotychczas w języku polskim, będących zapisem poszukiwań strategii walki, a także archiwum gorących dni powstania spartakusowców, gdy - jak się przynajmniej wtedy wydawało - „historia mogła być inna”23.

W radykalnej zmianie społecznej istotną rolę odgrywają różnego rodzaju podmioty polityczne łączące szeroki wachlarz demokratycznych postulatów. Dziś nie żywimy już przekonania, że ukształtują się one same z siebie, na mocy kryteriów ekonomicznych czy socjometrycznych. Róża Luksemburg zaś, bodaj jako pierwsza, dokonała błyskotliwej analizy kształtowania się rewolucyjnych podmiotowości oraz tożsamości politycznych w procesie samych walk i artykulacji różnorodnych żądań. Rozważania bohaterki tego numeru „Praktyki Teoretycznej” mogą być inspiracją dla dzisiejszej walki politycznej jako niezwykła - od strony teoretycznej i osobistej - analiza pewnej fenomenologii politycznej

$23 \mathrm{Na}$ temat subiektywnej historii alternatywnej działaczy robotniczych, którzy kreślą niezrealizowane „o włos” „uchronie” innej ścieżki historii zob. A. Portelli, The Death of Luigi Trastulli, and Other Stories: Form and Meaning in Oral History, Nowy Jork 1990. 
porażki, mozolnego przepracowywania kolejnych niepowodzeń, tak by stały się doświadczeniem możliwym do spożytkowania w toku przyszłych zmagań $^{24}$. Tę problematykę podejmują teksty Piotra Laskowskiego, Wiktora Marca i Kamila Piskały.

O znaczeniu, jakie dla dzisiejszej radykalnej lewicy ma postać Róży Luksemburg - traktowana nie jako martwy symbol, lecz jako inspirująca teoretyczka walki klas i demokracji radykalnej - świadczy doskonale seria wywiadów przeprowadzonych przez francuskiego socjologa Davida Muhlmanna z wybitnymi filozofami i ekonomistami. Dwa z nich publikujemy w niniejszym numerze. Są to rozmowy z Antonio Negrim oraz Michaelem Krätke, mało w Polsce znanym znakomitym ekonomistą marksistowskim i jednym z redaktorów MEGA2. Trzy kolejne rozmowy (z Michaelem Löwym, Danielem Bensaïdem i Isabel Loureiro) opublikowaliśmy na naszej stronie internetowej.

Wiele wskazuje na to, że dziś stoimy w punkcie zwrotnym procesu historycznego. Równie brzemiennym w skutki jak moment, w którym pisała Róża Luksemburg. Podobnie jak ona, w areszcie we Wronkach po klęsce ruchu robotniczego, jaką była I wojna światowa, poparta niemal jednogłośnie przez partie socjaldemokratyczne poszczególnych państw - możemy czuć się bezsilni. Luksemburg nie była orędowniczką „myśli słabej”, rezygnacji i fatalizmu. Jej niezwykła wrażliwość na niesprawiedliwość świata popychała do działania wbrew niepowodzeniom, zmuszała do nieprzerwanej walki o zmianę sytuacji. W tym też leży sens lekcji zadanej nam przez autorkę Akumulacji kapitatu. Wspomniana tymczasowa poprawa sytuacji pracowników i zuniwersalizowane świadczenia społeczne nie były efektem działania jakichś pozaziemskich sił, lecz zostały wywalczone przez ludzi, którzy świadomie tworzyli swoją historię. Wszystko, co mamy i kim jesteśmy, jest także ich zasługą. Dotychczasowe rewolucje były nieudane, ale być może to one właśnie przygotowują tę właściwą.

Redakcja „Praktyki Teoretycznej”

\section{Cytowanie:}

Kapitat powraca, „Praktyka Teoretyczna” 2012, nr 6 http://www.praktykateoretyczna.pl/PT nr6 2012 Roza Luksemburg/1.Wstep.pdf (dostęp dzień miesiąc rok)

24 Więcej zob. L. Michaelis, Rosa Luxemburg on Disappointment and the Politics of Commitment, "European Journal of Political Theory" 2011, No. 10. 